\title{
Effects of Blanching and Drying Treatment on the Phtyochemical Properties of Annona squamosa Peel
}

\author{
Nilam Roy and S. Sasikals* \\ Department of Food Process Engineering, School of Bioengineering, \\ Faculty of Engineering and Technology, SRM University, Kattankulathur - 603 203, India. \\ http://dx.doi.org/10.13005/bbra/2145
}

(Received: 10 March 2016; accepted: 20 April 2016)

\begin{abstract}
Processing of Annona squamosa (custard apple) generates considerable amount of wastes in the form of peels and seeds rich in phytochemicals which can be exploited to investigate its neutraceutical properties, and used as an alternative to synthetic food additives. The present study was designed to probe into the effects of blanching and drying treatment of the Annona squamosa peel. Results demonstrated that blanching and drying had considerable effects on colour and phytochemical properties of the powdered peel. The colour values revealed that the blanched-dried sample exhibited greater $L^{*}$ value $(74.590)$ at 7 min than the unblanched sample $(63.033)$ dried at $55^{\circ} \mathrm{C}$. An increasing trend of lightness $\left(\mathrm{L}^{*}\right)$ followed with the increase in blanching time and drying temperature. Antioxidant activity for unblanched sample dried at $50^{\circ} \mathrm{C}$ and sample blanched for $5 \mathrm{~min}$ and dried at $50^{\circ} \mathrm{C}$ exhibited better $\mathrm{IC}_{50}$ values of $104.712 \mathrm{ig} / \mathrm{ml}$ and $148.23 \mathrm{ig} / \mathrm{ml}$ respectively. The unblanched-dried $\left(50^{\circ} \mathrm{C}\right)$ and blanched-dried $\left(50^{\circ} \mathrm{C}-5 \mathrm{~min}\right)$ sample similarly exhibited better retention of total polyphenols, $20.06 \pm 0.6 \mathrm{mg} / \mathrm{mL}$ and $37.9 \pm 1.0 \mathrm{mg} / \mathrm{mL}$, respectively. Thus, this study suggests that combination of drying temperature of $50{ }^{\circ} \mathrm{C}$ and blanching time of $5 \mathrm{~min}$ are the optimum processing conditions for good retention of antioxidant property of Annona squamosa peel.
\end{abstract}

Key words: Annona squamosa (Custard apple) peel, Polyphenoloxidase, Blanching, Drying, Antioxidants, Polyphenols.

Annona squamosa Lin. is one of the most important member of the family Annonacea. It is an evergreen tree or shrub that yields the edible fruit Annona Squamosa, commonly known as "sugar apple or custard apple" branched tree or shrub typically grows in a tropical lowland climate without any irrigation. The Annona genus stems from the tropical climates of South America and West Indies, and is now cultivated in several other tropical countries like Sri Lanka, India, Thailand, Philippines, Malay Archipelago, Egypt, Central Africa and Australia. The fruit is round, ovate, heart-shaped or conical,

\footnotetext{
* To whom all correspondence should be addressed. E-mail: sasishan.shiva@gmail.com
}

$5-7.5 \mathrm{~cm}$ in diameter and $6-10 \mathrm{~cm}$ in length ${ }^{2}$. The white custard like pulp has sweet-sour flavour and the fruit contains 35-45 black seeds. Various traditional literature claim that custard apple and its related species (A. muricata, A.reticulata and A. cherimola) are effectively valuable against a vast array of diseases. The comestible portion of the fruit is rich in polyphenolic compounds, magnesium, copper, potassium, calcium, minerals, protein, carbohydrates and dietary fiber. Researchers have claimed that each and every part of the tree bark, stem, leaf, stem and seed possess therapeutic properties like antidiabetic, antihelmintic, antimicrobial and anticarcinogenic ${ }^{3}$. Herbal drugs developed from custard apple seeds were 300 times more effective than the anticancer drug, Taxol ${ }^{4}$. Aqueous extracts of Annona 
squamosa leaf (ethanolic and methanolic) have exhibited good antidiabetic properties in type 1 and type 2 diabetes ${ }^{5,6}$. The roots of the plant are beneficial in treating acute dysentery, spinal marrow diseases and depression while the leaves have been utilised in cases of sores, prolapse of the anus and swelling. In vivo study carried out on the peel extracts of custard apple exhibited that it possessed antihyperglycemic effect on streptozotocin diabetes induced mice ${ }^{7}$.

Custard apple processing, such as juice production, dehydrated flakes or freeze dried powder and extraction of flavouring compounds, produces waste materials in the form of peel and seeds. Numerous researches on fruits and vegetables have suggested that the compounds responsible for their neutraceutical properties are mainly concentrated on their peels ${ }^{8}$. Fresh custard apples when peeled are vulnerable to oxidation reactions due to the presence of polyphenols which act as the substrate for enzymatic oxidation?. The same can be observed for the white pith of the peel. Enzymatic oxidation reactions are triggered by the action of polyphenoloxidase enzyme. Hence, pretreatment before processing can be beneficial in inhibiting any considerable change of phytochemicals. Blanching is one such technique of arresting the action of the enzymes. The process essentially uses steam or hot boiling water as heat transfer medium. Generally, steam blanching is preferred over water blanching because water blanching causes leaching of many essential constituents during its process. The time and temperature applied during blanching brings about the desired inactivation, which also depends on the nature of the product being blanched. Apart from the pretreatment, drying is also a form of preservation to prolong and protect the perishable fruits and vegetables. Dehydration through drying preserves food by the removal of water which disables the microbe's ability to grow and survive. Microorganisms thrives well only when there is ample moisture content in its surrounding and ambient temperature for its survival. Thus, drying any food of perishable nature reduces moisture content which results in inhibition of growth and development of microbe. A detailed study of literature gave no evidence about the influence of blanching (steam blanching) and drying treatments on the peel of Annona squamosa, despite the in- vitro studies on raw peel's proximate analysis, hypoglycemic effect on rat models and other phytochemical constituents. Thus, this drove us to design the present study that probes into the influence of both blanching and drying treatments on the phytochemical properties of Annona squamosa fruit peel.

\section{Materials and Methodology}

The experimental analysis was carried out in the in the laboratories of the Department of Food Process Engineering, SRM University, Katankulathur, Tamil Nadu.

\section{Preparation of sample}

Fresh custard apple fruits were purchased from the nearby markets in Chennai. The fruits were thoroughly washed and skinned. The peel were collected and steam blanched for $3 \mathrm{mins}, 5 \mathrm{mins}$ and 7 mins to inactivate the polyphenoloxidase enzyme. The blanched and unblanched peel were then dried at $45^{\circ} \mathrm{C}, 50^{\circ} \mathrm{C}$ and $55^{\circ} \mathrm{C}$ in a tray drier until they attained constant weight. The unblanched peel sample served as the control. The dried peel were ground into powder and sealed in aluminium pouches for subsequent use.

\section{Preparation of the extract}

For the determination of the phytochemical properties i.e. antioxidant capacity and total phenolic content, the extract of the dried custard apple peel was prepared in accordance to the method described by Barros et al with some modifications as follows: $0.5 \mathrm{~g}$ of fine powdered peel was vortexed with $80 \%$ ethanol of $10 \mathrm{ml}$ volume, heated in a water bath for 3hours-4hours and centrifuged at $4000 \mathrm{rpm}$ for 10 minutes. The supernatant was filtered using Whatmann Filter paper No. 102 and stored at $4^{\circ} \mathrm{C}$ for future analyses. Dilution of the extract was carried when deemed necessary. All extract analysis was done in triplicates.

\section{Determination of Color Analysis}

Color analysis of the samples were done by Color Hunter Meter. Three readings were performed for each sample and mean values are shown in Table I.

\section{Determination of Total phenolic content}

Total phenolic content was evaluated in the ethanolic extracts according to Folin-Ciocalteu method with slight modifications in the dilution of the sample extract ${ }^{10,11}$. 
Determination of 2,2-diphenyl-1-picrylhydrazyl (DPPH) Radical Scavenging Activity

The antioxidant activity was assessed in accordance to the method described by Sutharsingh $\mathrm{R}$ et al., 2011 ${ }^{[12]}$. The antioxidant activity was calculated using the following formula:

$\%$ Radical scavenging activity $=\frac{\text { Absorbance } \text { control -absorbance sample } \times 100}{\text { Absorbance control }}$

\section{Statistical analysis}

Data were expressed as means \pm standard deviation (SD) of three replications and statistical analysis was done using SPSS program (version 19.0 SPSS Inc.). The values were considered to be significantly different when $\mathrm{p}<0.05$.

\section{RESULTS AND DISCUSSIONS}

\section{Color Analysis}

The physical appearance of the food in terms of its color plays a critical role in the acceptance of the food product by the consumers. The color changes during thermal processing can be assessed by the chromatic coordinates $\mathrm{L}^{*}$, $\mathrm{a}^{*}$ and $b^{*}$. The Color analysis of the blanched-dried and unblanched-dried samples by Hunter Color meter, depicted a marked difference in the $\mathrm{L}^{*}, \mathrm{a}^{*}$ and $b^{*}$ values. The blanched-dried samples gave a better color value since it had a greater $\mathrm{L}^{*}$ value as compared to the unblanched dried sample. The blanched-dried samples for 7 mins gave the greatest $\mathrm{L}^{*}$ value (74.590) than the other blanching variables $5 \mathrm{~min}$ and $3 \mathrm{~min}$. On the other hand, unblanched samples dried at $55^{\circ} \mathrm{C}$ gave the $\mathrm{L}^{*}$ value as 63.033 , whereas sample dried at $50^{\circ} \mathrm{C}$ had $\mathrm{L} * 63.42$, reason being that at $55^{\circ} \mathrm{C}$ the peel began charring and showed an increase in the $\mathrm{a}^{*}$ (redness) value. Table I and II summarizes the mean values of all samples. At the time of dehydration process, numerous changes triggered by enzymatic browning results in the color change of the unblanched samples. From Table II, it can be inferred that with the increase in blanching time, the peel powder had a lighter color than the unblanched samples in Table I at all drying temperatures assessed. This variation

Table 1. Color values with \pm s.d of samples dried without blanching

\begin{tabular}{lcccc}
\hline S. No & Drying Temperature $\left({ }^{\circ} \mathrm{C}\right)$ & \multicolumn{3}{c}{ Color Analysis } \\
\cline { 3 - 5 } & & $\mathrm{L}^{*}$ & $\mathrm{a}^{*}$ & $\mathrm{~b}^{*}$ \\
\hline 1. & 55 & $63.033 \pm 0.02^{\mathrm{b}}$ & $5.71 \pm 0.012^{\mathrm{b}}$ & $18.09 \pm 0.023^{\mathrm{a}}$ \\
2. & 50 & $63.42 \pm 0.015^{\mathrm{a}}$ & $5.72 \pm 0.02^{\mathrm{a}}$ & $17.32 \pm 0.030^{\mathrm{b}}$ \\
3. & 45 & $61.67 \pm 0.04^{\mathrm{c}}$ & $4.30 \pm 0.03^{\mathrm{c}}$ & $17.31 \pm 0.023^{\mathrm{b}}$ \\
\hline
\end{tabular}

*Data are expressed as mean \pm standard deviation. Data in the same column bearing different superscripts are statistically different at $5 \%$ level of significance $(\mathrm{p}<0.05)$

Table 2. Color values with \pm s.d of blanched-dried samples

\begin{tabular}{cccccc}
\hline \multirow{2}{*}{$\begin{array}{c}\text { S. } \\
\text { No }\end{array}$} & \multirow{2}{*}{$\begin{array}{c}\text { Drying } \\
\text { Temperature }\left({ }^{\circ} \mathrm{C}\right)\end{array}$} & $\begin{array}{c}\text { Blanching } \\
\text { time (mins) }\end{array}$ & $\mathrm{L}^{*}$ & $\mathrm{a}^{*}$ & $\mathrm{~b}^{*}$ \\
\cline { 4 - 6 } & & 7 & $74.59 \pm 0.07^{\mathrm{a}}$ & $4.14 \pm 0.03^{\mathrm{b}}$ & $17.54 \pm 0.021^{\mathrm{c}}$ \\
1. & 55 & 5 & $66.45 \pm 0.02^{\mathrm{b}}$ & $4.98 \pm 0.022^{\mathrm{a}}$ & $18.23 \pm 0.037^{\mathrm{b}}$ \\
2. & & 3 & $64.95 \pm 0.04^{\mathrm{c}}$ & $5.03 \pm 0.035^{\mathrm{a}}$ & $18.98 \pm 0.01^{\mathrm{a}}$ \\
3. & & 5 & $70.54 \pm 0.03^{\mathrm{a}}$ & $3.71 \pm 0.032^{\mathrm{b}}$ & $17.34 \pm 0.04^{\mathrm{c}}$ \\
4. & 50 & 3 & $68.93 \pm 0.4^{\mathrm{b}}$ & $3.57 \pm 0.015^{\mathrm{c}}$ & $20.05 \pm 0.02^{\mathrm{b}}$ \\
5. & & 5 & $63.55 \pm 0.12^{\mathrm{c}}$ & $5.603 \pm 0.026^{\mathrm{a}}$ & $20.11 \pm 0.024^{\mathrm{a}}$ \\
6. & 45 & $69.87 \pm 0.05^{\mathrm{a}}$ & $4.20 \pm 0.001^{\mathrm{c}}$ & $16.32 \pm 0.036^{\mathrm{b}}$ \\
7. & & 5 & $65.90 \pm 0.02^{\mathrm{b}}$ & $5.32 \pm 0.014^{\mathrm{a}}$ & $17.93 \pm 0.045^{\mathrm{a}}$ \\
8. & & & $63.79 \pm 0.04^{\mathrm{c}}$ & $5.18 \pm 0.026^{\mathrm{b}}$ & $16.28 \pm 0.021^{\mathrm{c}}$ \\
9. & & & & & \\
\hline
\end{tabular}

*Data are expressed as mean \pm standard deviation. Data in the same column bearing different superscripts are statistically different at $5 \%$ level of significance $(\mathrm{p}<0.05)$ 
in the color may be credited for the inactivation of the enzyme polyphenol oxidase by the blanching pretreatment. Similar findings were reported in the drying study of blanched and unblanched apple pomace, where significant differences were observed in the color of the dried pomace ${ }^{[13]}$.

\section{Total Phenolic Content}

The polyphenolic content of the blanched and the unblanched samples are summarized in Table III with standard deviation of the triplicates. The polyphenolic assay showed that the drying temperature and blanching showed a remarkable difference in the samples. The unblanched-dried samples exhibited less polyphenolic content compared to the blanched- dried samples. The drying temperature of $50^{\circ} \mathrm{C}$ exhibited better polyphenolic content for unblanched-dried $20.06 \pm 0.6 \mathrm{mg} / \mathrm{mL}$ and blancheddried sample at $50^{\circ} \mathrm{C}-5 \mathrm{~min} 37.9 \pm 1.0 \mathrm{mg} / \mathrm{mL}$ than rest of drying temperatures and blanching time. The loss of phenolic compounds during drying process is attributed to the fact that thermal processing results in the migration of certain compounds or changing their chemical nature making them susceptible to conditions of light, enzymatic activity and oxygen, especially the temperature and the duration used. The blanched samples with $3 \mathrm{~min}, 5 \mathrm{~min}$ and $7 \mathrm{~min}$ did show increase in polyphenolic content until it decreased for the $7 \mathrm{~min}$ blanched time for all evaluated

Table 3. Total phenolic content of samples with \pm S.D

\begin{tabular}{|c|c|c|c|c|c|}
\hline \multirow{3}{*}{$\begin{array}{l}\text { S. } \\
\text { No }\end{array}$} & \multirow{3}{*}{$\begin{array}{c}\text { Drying } \\
\text { Temperature }\left({ }^{\circ} \mathrm{C}\right)\end{array}$} & \multicolumn{4}{|c|}{ Total phenolic content $(\mathrm{mg} / \mathrm{ml})$} \\
\hline & & \multicolumn{3}{|c|}{ Blanched Samples } & \multirow{2}{*}{$\begin{array}{c}\text { Unblanched } \\
\text { samples }\end{array}$} \\
\hline & & $3 \mathrm{~min}$ & $5 \mathrm{~min}$ & $7 \mathrm{~min}$ & \\
\hline 1. & 55 & $26.78 \pm 1.0^{\mathrm{b}}$ & $31.89 \pm 0.6^{\mathrm{a}}$ & $20.67 \pm 0.3^{c}$ & $15.64 \pm 0.3^{\mathrm{d}}$ \\
\hline 2. & 50 & $32.04 \pm 0.5^{\mathrm{b}}$ & $37.9 \pm 1.0^{\mathrm{a}}$ & $29.60 \pm 0.6^{c}$ & $20.06 \pm 0.6^{\mathrm{d}}$ \\
\hline 3. & 45 & $29.86 \pm 0.3^{a}$ & $30.89 \pm 0.3^{\mathrm{a}}$ & $24.89 \pm 0.5^{b}$ & $16.87 \pm 0.4^{\mathrm{c}}$ \\
\hline
\end{tabular}

*Data are expressed as mean \pm standard deviation. Data in the same row bearing different superscripts are statistically different at $5 \%$ level of significance.

temperature conditions. The loss of phenolic content is not only dependent on the triggering of enzymes to initiate the enzymatic browning but also of the following: binding of polyphenolic compounds to other substrates (proteins), $\mathrm{pH}$ conditions, loss of organic acid and alterations in chemical conformations which cannot be ascertained or assessed by the available methodology ${ }^{[11]}$. Studies piloted by Lopez et al $(2010)^{[14]}$ demonstrated reduction in total polyphenols of blueberries as air drying temperatures increased compared to the initial polyphenolic content. The results of the present study was similar to the findings of Wolfe et al $(2003)^{[15]}$, where he reported that blanching the apple peels for 10 s and subsequent drying resulted in the better retention of polyphenolic compounds.

\section{Antioxidant Activity}

The antioxidant property for the blanched-dried peel and unblanched-dried peel was evaluated using DPPH methodology. The
DPPH methodology is broadly used to assess the free radical scavenging effect of both synthetic and natural antioxidants. The DPPH gives a deep violet color in any aqueous or alcoholic solutions, any substance possessing antioxidant activity donates hydrogen ion to DPPH reducing it into non-radical DPPH-H amber yellow color. The antioxidant values of unblanched-dried peel and blanched-dried peel at evaluated temperatures were compared with the standard BHT (Butylated hydroxy toluene) in Fig $\mathrm{I}$, and $\mathrm{IC}_{50}$ values were obtained. It can observed that the peel dried in range of $45-55^{\circ} \mathrm{C}$ temperatures had the highest radical scavenging activity at $50^{\circ} \mathrm{C}$ with $\mathrm{IC}_{50}$ at $148.23 \mu \mathrm{g} / \mathrm{mL}$ and in the blanched-dried samples drying temperature along with blanching time played a considerable role in the antioxidant property. Best antioxidant property was exhibited in the sample blanched for $5 \mathrm{~min}$ and dried at $50^{\circ} \mathrm{C}$ with $\mathrm{IC}_{50}$ at $104.712 \mu \mathrm{g} / \mathrm{mL}$, when compared with the $\mathrm{IC}_{50}$ of BHT at $43.85 \mu \mathrm{g} / \mathrm{mL}$. The results obtained 


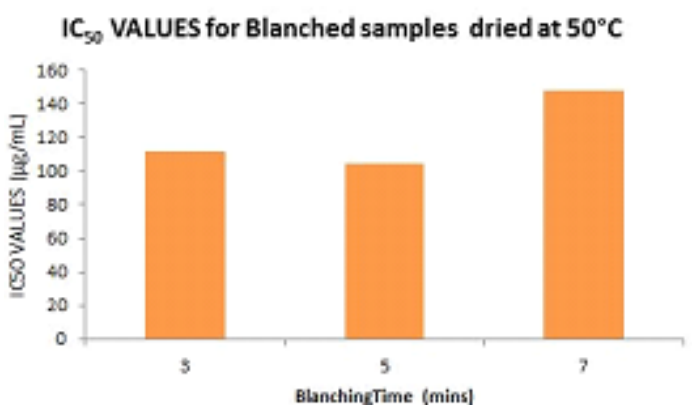

Fig. 1. DPPH Radical Scavenging activity \% of Unblanched samples with Standard BHT

\section{Unbalanched Samples IC50 VALUES $(\mu \mathrm{g} / \mathrm{mL})$}

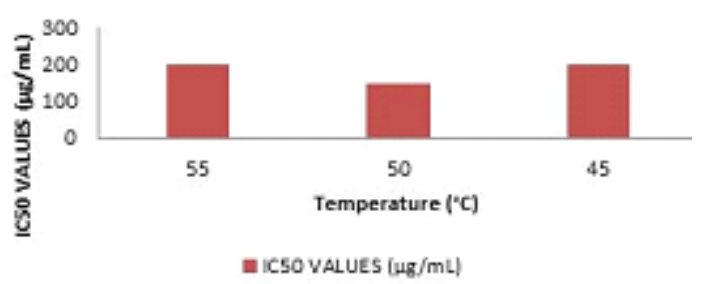

Fig. 2. IC50 Values for Radical Scavenging Activity \% of Unblanched Samples

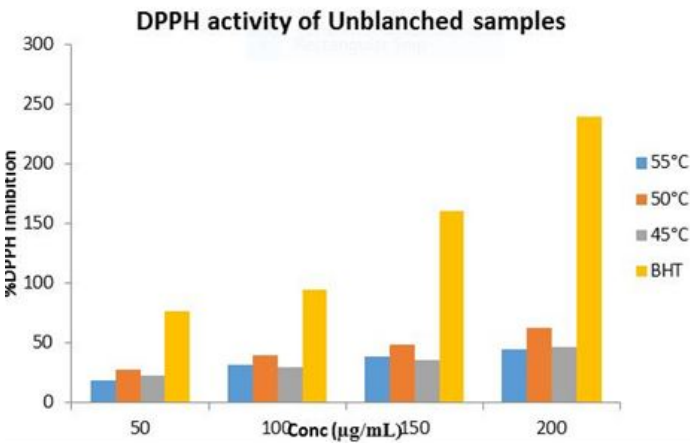

Fig. 3. IC50 Values for Radical Scavenging Activity $\%$ of Blanched Samples at $50^{\circ} \mathrm{C}$

are in accordance with the amount of polyphenolic content of the samples thus suggesting that the retention of polyphenolic contents are responsible for antioxidant property. Similar reports were concluded in the study of drying and blanching of apple pomace conducted by Ramirez et al. $(2011)^{[13]}$, where blanched apple pomace showed the highest antioxidant activity compared to peels not blanched. Likewise, Chantaro et al (2008) ${ }^{[16]}$ described in his study that dehydrating the carrot peel lead to the reduction of antioxidant capacity with correlation to the loss of total polyphenols.

\section{CONCLUSION}

Thus, it can be concluded that pretreating methods like blanching is effective in retarding the oxidation reactions by the native enzymes present in the fruit peel. This method increases the phytochemical constituents of the peel responsible for its antioxidant activity and total phenols. From the current study, thus it can be deduced that blanching time of $5 \mathrm{mins}$ and drying temperature of $50^{\circ} \mathrm{C}$ are the optimum conditions to process the custard apple peel, as the results have demonstrated statistically significant $p<0.05$. than the other evaluated conditions.

\section{REFERENCES}

1. Mst. Shahnaj Parvin, Md Islam Ekramul, Md Rahman Motiur and Md Haque Ekramul. "Pesticidal activity of pure compound Annotemoyin-1 isolated from chloroform extract of the plant Annona squamosa linn. Against Tribolium castaneum (Herbst)," Pak J Biol Sciences., 2003; 12( 6) :1088- 1091.

2. FAO. 1990. Utilization of tropical food, fruits and leaves. FAO Food and Nutrition Paper, 1990; 47(7): pp. 10-14.

3. K. W. Pomer, J. Lowe, S. Crabtree and Keller. Identification of Annonaceous acetogenins in the ripe fruit of the North American pawpaw (Asimina triloba). J Agric Food Chem., 2009; 57: 8339-43.

4. B. V. Parthasaradhi, M. Reddy, M. Ali, L. Kumari. Antitumor activity of Annona squamosa seed extract is through the generation of free radicals and induction of apoptosis. Indian $J$ Biochem Biophys., 2004; 41: 167-72.

5. R. K. Gupta., A. N. Kesari, G. Watal, P. S. Murthy, R. Chandra, K. Maithal, V. Tandon. Hypoglycaemic and antidiabetic effect of aqueous extract of leaves of Annona squamosa (L.) in experimental animal. Current Science, 2005; 88.

6. V. S. Nandagaon and A. R. Kulkarni. In vitro Antioxidant and Cytotoxicity Activity of Aqueous and Alcoholic Extracts of Annona Squamosa Linn. Research Journal of Pharmaceutical, Biological and Chemical Sciences, 2012; 3: 479-482. 
7. A. Sharma., T. Chand, M. Khardiya, K. C. Yadav, R. Mangal and K. A. Sharma. Antidiabetic and Antihyperlipidemic Activity of Annona Squamosa Fruit Peel in Streptozotocin Induced Diabetic Rats. International Journal of Toxicological and Pharmacological Research, 2013; 1(5): 15-21,

8. K. J. Kamble and S. B. Soni. Effect of steam blanching on quality of custard apple pulp. Journal of Horticulture and Forestry, 2010; 2: 104-107.

9. L. Barros, J. Pinela Dueñas M, Carvalho AM, Santos-Buelga C, et al. Antioxidant activity, ascorbic acid, phenolic compounds and sugars of wild and commercial Tuberaria lignosa samples: Effects of drying and oral preparation methods. Food Chem, 2012; 135: 1028-1035.

10. M. I. S. Abdelhady, A. A. Motaal and L. Beerhues. Total Phenolic Content and Antioxidant Activity of Standardized Extracts from Leaves and Cell Cultures of Three Callistemon Species. Am J Plant Sci., 2011; 2: 847-50.

11. N. D. Mrad, N. Boudhrioua, N. Kechaou, F. Courtois, C. Bonazzi. Influence of air drying temperature on kinetics, physicochemical properties, total phenolic content and ascorbic acid of pears. Food Bioprod Proc., 2012; 90: 433-441.
12. Sutharsingh, R., Kavimani, S., Jayakar, B., Uvarani, M. and Thangathirupathi, A. Quantitave phytochemical estimation and antioxidant studies on aerial parts of Naravelia zeylanica DC. Int. J. Pharm. Studies Res, 2011; 2: $52-56$.

13. M. E. Heras-Ramirez, A. Quintero-Ramos, A. A. Camacho-Davila, J. Barnard, R. TalamasAbbud, J. V. Torres-Munoz and Erica SalasMunoz. Effect of Blanching and Drying Temperature on Polyphenolic Compound Stability and Antioxidant Capacity of Apple Pomace. Food Bioprocess Technol, 2012; 5: 2201-2210.

14. J. Lopez, E. Uribe, A. Vega-Gálvez, M. Miranda, J. Vergara, E. Gonzalez. Effect of air temperature on drying kinetics, vitamin $\mathrm{C}$, antioxidant activity, total phenolic content, non-enzymatic browning and firmness of blueberries variety O’Neil. Food and Bioprocess Technol., 2010; 3: 772-777.

15. K. Wolfe and R. Hai-Liu. Apple peels as a valueadded food ingredient. Journal of Agricultural and Food Chemistry, 51: 1676-1683, 2003.

16. P. Chantaro, S. Devahastin and N. Chiewchan. Production of antioxidant high dietary fiber powder from carrot peels. LWT Food Sci Technol., 2008; 41: 1987-1994. 